\title{
A comparison of clinical assessments of disease activity in rheumatoid arthritis
}

\author{
V. M. RHIND, H. A. BIRD, AND V. WRIGHT \\ From the Clinical Pharmacology Unit, Royal Bath Hospital, Harrogate, and the Rheumatism Research Unit, \\ University Department of Medicine, General Infirmary, Leeds
}

SUMMARY Six clinical assessments of disease activity, including a new summated change scale (SCS), have been compared in a group of 30 patients with rheumatoid arthritis seen on 8 separate occasions during their first 6 months of therapy with either D-penicillamine or hydroxychloroquine. Articular index and grip strength correlate best with erythrocyte sedimentation rate and C-reactive protein, pain score and early morning stiffness less well, and summated change score and joint circumference least well. Articular index and grip strength also correlated well with the other clinical parameters and are therefore judged to be the best clinical indices of change in treatment with these drugs.

Pain rating scales and visual analogue scales are widely used in the assessment of disease activity and the response of patients to treatment in the rheumatic diseases (Huskisson, 1976), though a previous study from this unit (Downie et al., 1978) showed a relatively poor correlation between measured and assessed values when a visual analogue scale was used to estimate grip strength. It is common in clinical trials to seek the patient's view of how they feel their condition has changed compared with the last attendance. We therefore felt a quantitative global assessment change scale might be a useful addition to clinical assessments already in existence. This summated change scale (SCS) is based on a subjective visual analogue scale. Its performance has been compared with other clinical assessments in a group of patients with rheumatoid arthritis during their first 6 month's treatment with either D-penicillamine or hydroxychloroquine. We also correlated the clinical assessments with the erythrocyte sedimentation rate (ESR) and C-reactive protein (CRP) estimations, probably the 2 laboratory tests most frequently used to monitor rheumatoid disease.

\section{Patients and methods}

A group of 30 patients with classical or definite rheumatoid arthritis (American Rheumatism Asso-

Accepted for publication 30 March 1979

Correspondence to Dr H. A. Bird, Clinical Pharmacology Unit, Royal Bath Hospital, Cornwall Road, Harrogate HG1 2PS. ciation criteria) were each assessed throughout the first 6-month period of treatment with either D-pencillamine (15 patients; $125-500 \mathrm{mg} /$ day) or hydroxychloroquine (15 patients; $200 \mathrm{mg}$ twice daily). The only other drug therapy allowed was enteric-coated aspirin and steroids in constant dosage.

All showed moderate to severe disease activity judged by the presence of at least 3 of the following 5 criteria: (a) tenderness of more than 6 joints; $(b)$ swelling of more than 3 joints; $(c)$ morning stiffness of more than 45 minutes; $(d)$ articular index of more than 20; (e) ESR of more than $28 \mathrm{~mm} / 1$ st hour.

The patients were seen by the same observer (V.R.) at each of 8 regularly spaced clinic visits, when the following assessments were recorded:

(a) Articular index (Ritchie et al., 1968).

(b) Grip strength, measured by a sphygmodynamometer inflated to $30 \mathrm{mmHg}$. A mean of 6 readings, 3 for each hand measured alternatively, was taken.

(c) Joint circumference of 10 proximal interphalangeal joints measured by a Geigy arthrocircometer. The mean of 10 readings was taken.

(d) Duration of morning stiffness measured in minutes. This was recorded daily on a diary card and the mean of the values for the week prior to each assessment taken.

(e) Pain recorded daily by the patient on a diary card using a $1-5$ pain rating scale (PRS): $1=$ no pain, $2=$ mild pain, $3=$ moderate pain, $4=$ severe pain, $5=$ very severe pain. The mean of the readings for the week prior to each assessment was taken. 
( $f$ ) Global assessment by means of our summated change scale (SCS) a modified visual analogue scale. This is a $20 \mathrm{~cm}$ line with the midpoint marked. At one end are the words 'best possible' and at the other 'worst possible' (Fig. 1). The midpoint represents how the patient felt at the previous clinic visit. At the second and subsequent visits the patient is asked to express by marking a cross on the scale how much better or worse he feels. If he feels his condition is unchanged, he marks the midpoint. Global change is assessed by measuring the distance between cross and midpoint, expressed as a plus or minus value, summated over the 6-month period, a positive value denoting improvement.

At each visit the ESR and CRP measured by gel diffusion (Crockson, 1963) were also recorded. The Pearson correlation coefficients with paired data for each individual patient at each clinic visit were calculated.

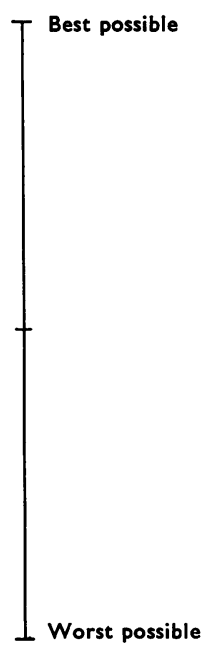

Fig. $120 \mathrm{~cm}$ line for summated change scale

\section{Results}

A correlation matrix between the clinical and laboratory variables measured inthe 30 patients is shown in Table 1. Of the clinical parameters assessed, articular index and grip strength correlated best with ESR and CRP. PRS and early morning stiffness correlated less well and SCS and joint circumference least well with the laboratory parameters. Thus, of the purely subjective assessments PRS performed slightly better than SCS.

Of the correlations between clinical parameters articular index showed the best and joint circumference the worst.

\section{Discussion}

Although the SCS is a simple, attractive idea for the assessment of response to 'long term' antirheumatoid drug therapy, it performed less well than a daily 1-5 pain rating scale at mirroring ESR and CRP. These particular laboratory indices have been shown to correlate both with disease activity in rheumatoid arthritis (Haataja and Kalliomaki, 1978) and with other laboratory variables in this condition (Dixon et al., in preparation). The failure of the SCS may be due to the patient's inability to use the change scale or, more probably, to their inability to remember accurately how they felt at the previous clinic visit.

The articular index, correlating well with other clinical parameters and with ESR and CRP, reflects the advantages of a scoring system considering a large number of joints in a semiobjective manner. By contrast, joint circumference, reflecting a single group of joints not always involved in rheumatoid disease, correlates poorly with clinical and laboratory parameters. Articular index appears to be the clinical assessment of choice when rheumatoid arthritis is first treated with hydroxychloroquine or D-penicillamine.

Table 1 Correlation matrix between clinical and laboratory variables measured in 30 patients on 8 occasions over a 6-month period

\begin{tabular}{|c|c|c|c|c|c|c|c|c|}
\hline $\begin{array}{l}\text { Erythrocyte } \\
\text { sedimentation } \\
\text { rate }\end{array}$ & $\begin{array}{l}\text { C-reactive } \\
\text { protein }\end{array}$ & $\begin{array}{l}\text { Summated } \\
\text { change } \\
\text { scale }\end{array}$ & $\begin{array}{l}\text { Pain } \\
\text { score }\end{array}$ & $\begin{array}{l}\text { Early } \\
\text { morning } \\
\text { stiffness }\end{array}$ & $\begin{array}{l}\text { Articular } \\
\text { index }\end{array}$ & $\begin{array}{l}\text { Grip } \\
\text { strength }\end{array}$ & $\begin{array}{l}\text { Joint } \\
\text { circum- } \\
\text { ference }\end{array}$ & \\
\hline 1.00 & 1.00 & $\begin{array}{r}-0.09 \\
1.00\end{array}$ & $\begin{array}{r}0.37 \\
-0.34 \\
1.00\end{array}$ & $\begin{array}{r}0.20 \\
-0.27 \\
0.33 \\
1 \cdot 00\end{array}$ & $\begin{array}{r}0.46 \\
-0.28 \\
0.47 \\
0.37 \\
1.00\end{array}$ & $\begin{array}{r}-0.29 \\
0.20 \\
-0.33 \\
-0.23 \\
-0.52 \\
1.00\end{array}$ & $\begin{array}{r}0.10 \\
0.24 \\
-0.09 \\
-0.01 \\
-0.14 \\
0.36 \\
1.00\end{array}$ & $\begin{array}{l}\text { C-reactive protein } \\
\text { Summated change scale } \\
\text { Pain score } \\
\text { Early morning stiffness } \\
\text { Articular index } \\
\text { Grip strength } \\
\text { Joint circumference }\end{array}$ \\
\hline
\end{tabular}


We thank Mrs P. Leatham for help with clinical assessments, Mr J. R. Lowe and Mr J. S. Dixon for expert technical assistance, $\mathrm{Mr} \mathrm{C}$. Hallett for statistical advice, and Mrs D. K. Smith for typing the script.

The Clinical Pharmacology Unit acknowledges the financial support of Roche Products Ltd.

\section{References}

Crockson, R. A. (1963). A gel diffusion precipitin method for estimation of C-reactive protein. Journal of Clinical Pathology, 16, 287-289.

Dixon, J. S., Pickup, M. E., Lowe, J. R., Hallett, C., Lee, M. R., and Wright, V. (In preparation). Discriminatory indices of response of patients with rheumatoid arthritis treated with D-penicillamine.
Downie, W. W., Leatham, P. A., Rhind, V. M., Pickup, M. E., and Wright, V. (1978). The visual analogue scale in the assessment of grip strength. Annals of the Rheumatic Diseases, 37, 382-384.

Haataja, M., and Kalliomaki, J. L. (1978). Laboratory scale for evaluating the activity of RA. Rheumatism and Rehabilitation, 17, 83-85.

Huskisson, E. C. (1976). Assessment for clinical trials Clinics in Rheumatic Diseases, 2, 37-49.

Ritchie, D. M., Boyle, J. A., McInnes, J. M., Jasani, M. K., Dalakos, T. G., Grieveson, P., and Buchanan, W. W. (1968). Clinical studies with an articular index for the assessment of joint tenderness in patients with rheumatoid arthritis. Quarterly Journal of Medicine, 37, 393-406. 